\title{
THE PLANTATION MACHINE
}




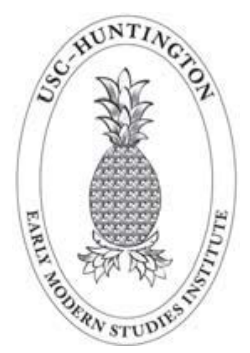

THE EARLY MODERN AMERICAS

Peter C. Mancall, Series Editor

Volumes in the series explore neglected aspects of early modern history in the western hemisphere. Interdisciplinary in character, and with a special emphasis on the Atlantic World from 1450 to 1850 , the series is published in partnership with the USC-Huntington Early Modern Studies Institute. 


\title{
THE PLANTATION MACHINE
}

ATLANTIC CAPITALISM

IN FRENCH SAINT-DOMINGUE

AND BRITISH JAMAICA

\section{TREVOR BURNARD \\ AND \\ JOHN GARRIGUS}

\author{
$\overline{\text { PENN }}$ \\ UNIVERSITY OF PENNSYLVANIA PRESS \\ PHILADELPHIA
}


Copyright (C) 2016 University of Pennsylvania Press

All rights reserved. Except for brief quotations used for purposes of review or scholarly citation, none of this book may be reproduced in any form by any means without written permission from the publisher.

$$
\begin{gathered}
\text { Published by } \\
\text { University of Pennsylvania Press } \\
\text { Philadelphia, Pennsylvania 19104-4112 } \\
\text { www.upenn.edu/pennpress }
\end{gathered}
$$

Printed in the United States of America on acid-free paper 13579108642

Cataloging-in-Publication Data is available from the Library of Congress.

ISBN 978-0-8122-4829-6 